\title{
Characteristics of Von Bertalanffy Growth, Allometric, Condition Index and Mortality of Periophthalmus barbarus in Mangrove and Bekantan Conservation Area (KKMB), Tarakan, North Kalimantan
}

\author{
Agus Indarjo1,2, Gazali Salim³*, Mufrida Zein ${ }^{4}$, Susiyanti $^{3}$, Permana Ari Soejarwo5, \\ Christine Dyta Nugraeni ${ }^{6}$, Stephanie Bija ${ }^{6}$ and Yen Thi Hong Pham ${ }^{7}$ \\ ${ }^{1}$ Department of Marine Science, Faculty of Fisheries and Marine Science, \\ Diponegoro University, J. Prof. H. Soedarto, S.H. Tembalang Semarang, 50275 Indonesia \\ 2 Director of Vocational of Indonesian Ministry of Education and Culture, \\ JI. Jend Sudirman, Pintu I, Senayan Jakarta 10270 Indonesia \\ ${ }^{3}$ Department of Waters Resources Management, Faculty of Fisheries and Marine Science, \\ University of Borneo Tarakan, Jl. Amal Lama, Tarakan, North Kalimantan, Indonesia \\ ${ }^{4}$ Department of Accounting, Politeknik Negeri Tanah Laut \\ Jl. A. Yani No.Km.06, Pemuda, Tanah Laut, South Kalimantan, 70815 Indonesia \\ 5Indonesian Center for Social and Economic Research, Ministry of Maritime Affairs and Fisheries, \\ J. Medan Merdeka Timur No. 16, Jakarta 10110 Indonesia \\ ${ }^{6}$ Department of Fisheries Product Technology, University of Borneo Tarakan \\ J. Amal Lama, Tarakan, North Kalimantan, Indonesia \\ ${ }^{7}$ Department of International Business, National Kaohsiung University of Science and Technology \\ No 415, Jiangong Rd., Sanmin Dist., Kaohsiung City 807, Taiwan
}

Email: axza_oke@yahoo.com

\begin{abstract}
The Mudskipper ( $P$. barbarus) lives in intertidal mud flats and it becomes an indicator of water quality. The transformation of construction and water pollution in this area is important to investigate due to interaction of fishery industry, home residence, and market area surrounding areas. The aim of this research was to analyze the characteristic of Von Bertalanffy growth, allometric, condition index, and mortality of the P. barbarus in KKMB, Tarakan city. The research was designed by using descriptive quantitative method. The sampling process used purposive sampling. The sampling was conducted for 12 times plot/transect in the extension area of KKMB, Tarakan city with a total area is $12 \mathrm{Ha}$, transect area is $10 \times 10 \mathrm{~m}^{2}$, and distance between each transect is $10 \mathrm{~m}^{2}$. Sampling was carried out in survey area and laboratory to identify the gender and calculate total length and weight. The result showed the growth of male mudskipper $(L \infty=26.545 \mathrm{~cm})$ and female $(L \infty=17.594 \mathrm{~cm})$. Their size and the total population was decreased. The characteristic of male mudskipper growth was positive allometric, then female was negative allometric. The natural mortality and the catch of male mudskipper were higher than female.
\end{abstract}

Keywords: growth, population, mudskipper fish,

\section{Introduction}

Mangrove and Bekantan Conservation Area (KKMB), Tarakan city, is one of the conservation areas in Indonesia. There are many species of aquatic and terrestrial natural resources. This area belongs to the green zone in central Tarakan city and integrated with industry area, home residence, and market area. According to Salim et al. (2018), the ecosystem of mangrove forests and coastal is part of the ecosystem, which is influenced by the tide. One of the coastal ecosystems is a muddy beach that consists of a mangrove forest.

Mangrove forest correlates with producer and the nutrient provider for aquatics organisms, such as the mudskipper (Periophthalmus barbarus). Jamiludin and Salim (2016), clarify that the mudskipper is an aquatic biota that lives in the coastal area and can survive in the ground around 5 minutes. The specific characteristic of the mudskipper is protruding eyes at the top of the head. According to Jamiludin and Salim (2016), the protuberant head has a relation with the gender of the fish, especially in adult fish. The size of male mudskipper's protuberant is more significant than that of the female.

The existence of $P$. barbarus in the muddy coastal ecosystem could use as one of the quality water indicators in KKMB, Tarakan City. The recent research by Jamiludin and Salim (2016) found that 
the population of female $P$. barbarus (54.4\%) is more than that of males (45.6\%). The population density of the mudskipper is around $0.34+0.17$ ind. $\mathrm{m}^{-2}$. Salim, et al. (2018) reported that the growth properties of male and female mudskipper was negative allometric and the body of them is fat. While Firdaus and Salim (2018), found that the growth properties of them is negative allometric. The body shape of male Atlantic mudskipper is fat, but the female is flat. The maximum length of male Mudskipper was $27.374 \mathrm{~cm}$, and the female was $20.683 \mathrm{~cm}$. The natural mortality of the female and male $P$. barbarus was $11.6 \%$ and $18.3 \%$, respectively.

However, study on natural growth and environmental (pollution) effects on the growth and mortality of $P$. barbarus in KKMB, Tarakan city is very limited. This study aims to analyze the Von Bertalanffy growth model, allometric growth, condition index, and mortality of $P$. barbarus in KKMB, Tarakan city.

\section{Materials and Methods}

The sampling was done with 12 times transect in the extension area of Mangrove and Bekantan Conservation Area (KKMB), Tarakan City. The size of the transect was $10 \times 10 \mathrm{~m}^{2}$. The distance of each transect was $10 \mathrm{~m}$. Four coordinate points determinate by GPS. The sample was taken when it was low tide. Sampling was done following (Salim et al., 2018). The sample were put in a plastic bags and kept in the freezer.

The mudskipper was measured its length and weight (Effendie, 1979; Salim et al., 2018). The determination of mudskipper's gender based on research of Jamiludin and Salim (2016).

\section{Variable of Von Bertalanffy Model}

Variable of growth used Von Bertalanffy model (Sparre and Venema, 1998):

$$
L t=L \infty\left(1-e^{-k(t-t 0)}\right)
$$

Note: $\mathrm{Lt}=$ Length of the mudskipper ( $P$. barbarus) with age $t$ (unit of time); $L \infty=$ Maximum length of the mudskipper ( $P$. barbarus) theoretically (asymptotic length); $\mathrm{K}=$ Coefficient growth of the mudskipper ( $P$. barbarus) (per unit of time); to $=$ Theoretical age of the mudskipper ( $P$. barbarus) when the length is zero

\section{Variable of age structure}

Variable of age structure used modus class shift method that has correlation with Von Bertalanffy based on Sparre et al. (1998) as follows:

$$
\begin{aligned}
(\Delta \mathrm{L} / \Delta \mathrm{t}) & =\left(\mathrm{L}_{2}-\mathrm{L}_{1}\right) /\left(\mathrm{t}_{2}-\mathrm{t}_{1}\right) \\
\mathrm{L}_{(\mathrm{t})} & =\left(\mathrm{L}_{2}+\mathrm{L}_{1}\right)
\end{aligned}
$$

Note: $\Delta \mathrm{L} / \Delta \mathrm{t}=$ Relative growth; $\Delta \mathrm{L}=$ Length of the $P$. barbarus; $\Delta \mathrm{t}=$ Difference of sampling time; $\mathrm{L}_{(\mathrm{t})}=$ Modus of average length

The equation of the linear curve was obtained by plot between $\mathrm{L}_{(\mathrm{t})}$ and $(\Delta \mathrm{L} / \Delta \mathrm{t})$ value to obtain the following linear line equation:

$$
Y=a+b x
$$

Note: $\quad a=\left(\left(\sum y / n\right)-\left(b\left(\sum x / n\right)\right)\right) ; b=\left(n \sum(x y)-\left(\sum x\right)(\right.$ $\left.\left.\sum \mathrm{y}\right)\right) /\left(\mathrm{n} \sum \mathrm{x}^{2}-\left(\sum \mathrm{x}\right)^{2}\right)$

The average value of modus length obtained from the regression equation method is used to calculate the asymptotic length $(L \infty)=-a / b$, then the growth coefficient is $-b$. Age theoretical of $P$. barbarus when the length is zero can be expected separately by empirical equation (Pauly in Sparre and Venema, 1998) ;

$$
\log \left(-t_{0}\right)=0,3922-0,275(\log \operatorname{L} \infty 1,038(\log K)
$$

Note: L $\infty=$ asymptotic length of $P$. barbarus $(\mathrm{cm}) ; \mathrm{K}=$ growth rate coefficient of $P$. barbarus; $t_{0}=$ Age theoretical of $P$. barbarus when the length is zero (year)

\section{Allometric growth model}

The allometric growth model was the length and weight value to analyze population growth overall. The estimation based on Effendie (1979) :

$$
Y=a+X^{b} \quad \text { or } \quad \log Y=\log a+b \log X
$$

Note: $Y=$ Total weight of $P$. barbarus (gram); $X=$ Total lenght $P$. barbarus $(\mathrm{mm}) ; a+b=$ coefficient (intercept)

The value of $b$ was an allometric coefficient that reflected relative growth. When $b$ value $=3$, allometric growth characteristic was isometric, length growth was the same with weight growth. b value $<3$ (allometric negative) or $b>3$ (allometric positive), so length growth was not same with weight growth. The correlation between length and weight calculated by correlation coefficient Effendie (1979).

\section{Condition index model}

Condition in dex of the fish was based on five criteria i.e. very flat fish (0.01-0.50), flatfish boy (0.51-0.99), proportional/ideal fish (1), fat fish (1.01-1.50), and the obese fish (>1.50) (Firdaus and Salim, 2011; Salim, 2013; Salim 2015; Firdaus et al., 2018). 
The allometric growth used Weatherley (1972) and isometric growth used Lagler (1949) and Effendie (1979) method. Based on Lagler (1949) in Effendie (1979) to obtain fish condition factor with isometric growth characteristic can used this equation as follows:

$$
K_{(\mathrm{TI})}=10^{5} x \frac{w}{L^{3}}
$$

$\mathrm{w}=$ total weight of fish (gr);

$\mathrm{L}=$ total length of fish $(\mathrm{mm})$;

$10^{5}=$ the equation was taken, so $K_{(\mathrm{TI})}$ value is close to 1 .

The fish condition factor with fish allometric characteristic used this equation Weatherley (1972):

$$
K n=\frac{\hat{W}}{W}
$$

$W=$ total weight of of fish (gr);

$\hat{\mathrm{w}}=$ allegation of total weight of fish (gr);

$\mathrm{W}=\mathrm{a} \mathrm{L} b$ obtained using the regression equation of length-weight) correlation.

\section{Variable of mortality}

Natural mortality (M) is estimated using Pauly's empirical formula (1984), which is:

$$
\begin{gathered}
\log M=0,00660,279 \log L \infty+0,6543 \log K+ \\
0,4634 \log T
\end{gathered}
$$

Total mortality $(Z)$ is estimated using the Beverton and Holt formula (Sparre and Venema, 1998) as follows:

$$
\mathrm{Z}=\mathrm{K} \cdot\left[\frac{\mathrm{L}_{\infty}-\bar{L}}{\bar{L}-L^{\prime}}\right]
$$

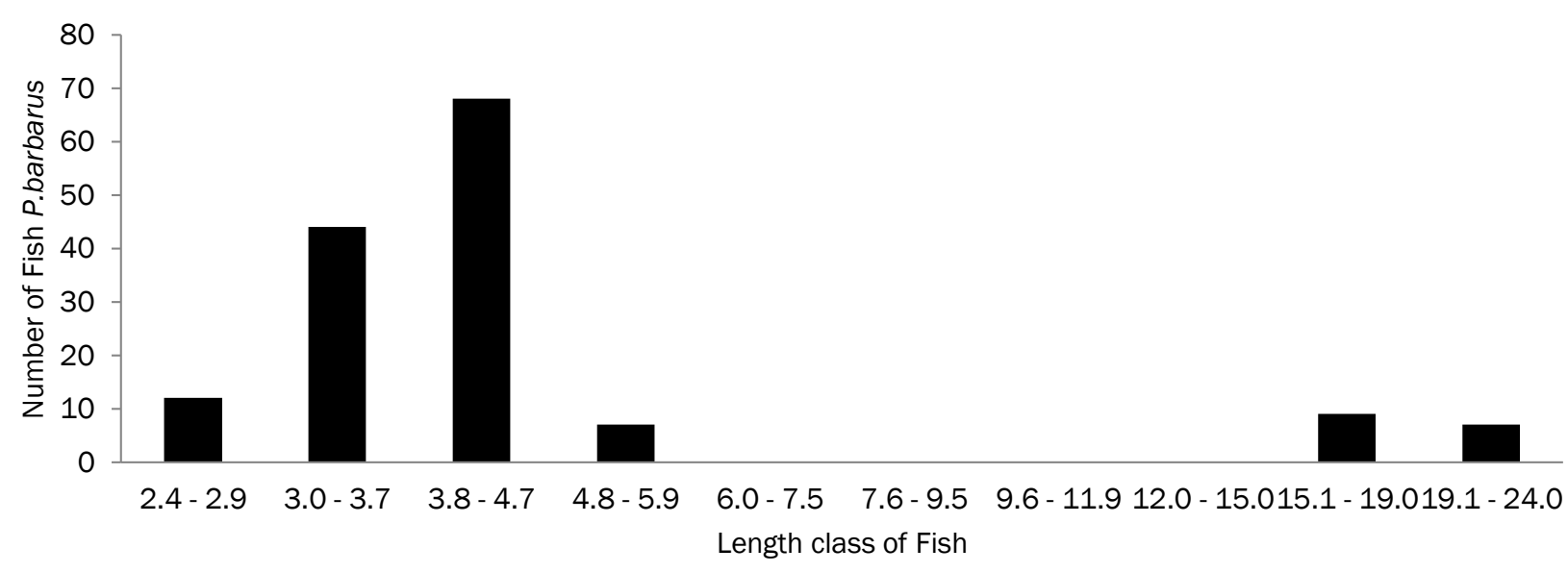

Figure 1. Distribution structure length of male $P$. barbarus in KKMB
Mortality Capture (F) as follows: $F=Z-M$ The exploitation rate $(E)$ is drawn as follows using the formulation of Baranov (Sparre and Venema, 1998). Note : $E=$ Rate of exploitation; $Z$ = Total mortality; $\mathrm{F}=$ Capture mortality; $\mathrm{M}=$ Natural mortality

\section{Result and Discussion}

\section{Distribution structure}

This research obtained 296 fishes which were 147 male (49.66\%), and 149 female mudskippers (50.34\%). Length distribution of male mudskipper was $4.25 \pm 0.45 \mathrm{~cm}$ for 68 fish (46.26\%), but the size between $10.5+4.5 \mathrm{~cm}$ was not found (Figure 1 ). The majority of female mudskipper length was $6.9 \pm 0.6$ $\mathrm{cm}$. The length size around $10.3 \pm 1 \mathrm{~cm}$ is not found (Figure 2). The distribution of female $P$. barbarus is higher than male and the size for male was $10.5+$ $4.5 \mathrm{~cm}$ and for $10.3+1 \mathrm{~cm}$ was not found due to the spawning at the time, so the $P$. barbarus were keeping their nests. In accordance with Nash (1984); Silva and Gordo, 1997 explained that during the spawning period, the existence of female and male fish was decreased.

The female mudskipper with the big size is rarely found than that of the small fish. It indicates that there is size degradation cause natural mortality in the male mudskipper as $53.14 \%$ and female as $52.54 \%$. The exploitation of male and female mudskipper as medicine is around $83.77 \%$ and $80.77 \%$, respectively. See Figure 3 and 4 .

\section{Von Bertalanffy model}

Von Bertalanffy model based on age structure explain about correlation between total length of male $P$. barbarus and growth rate. The 


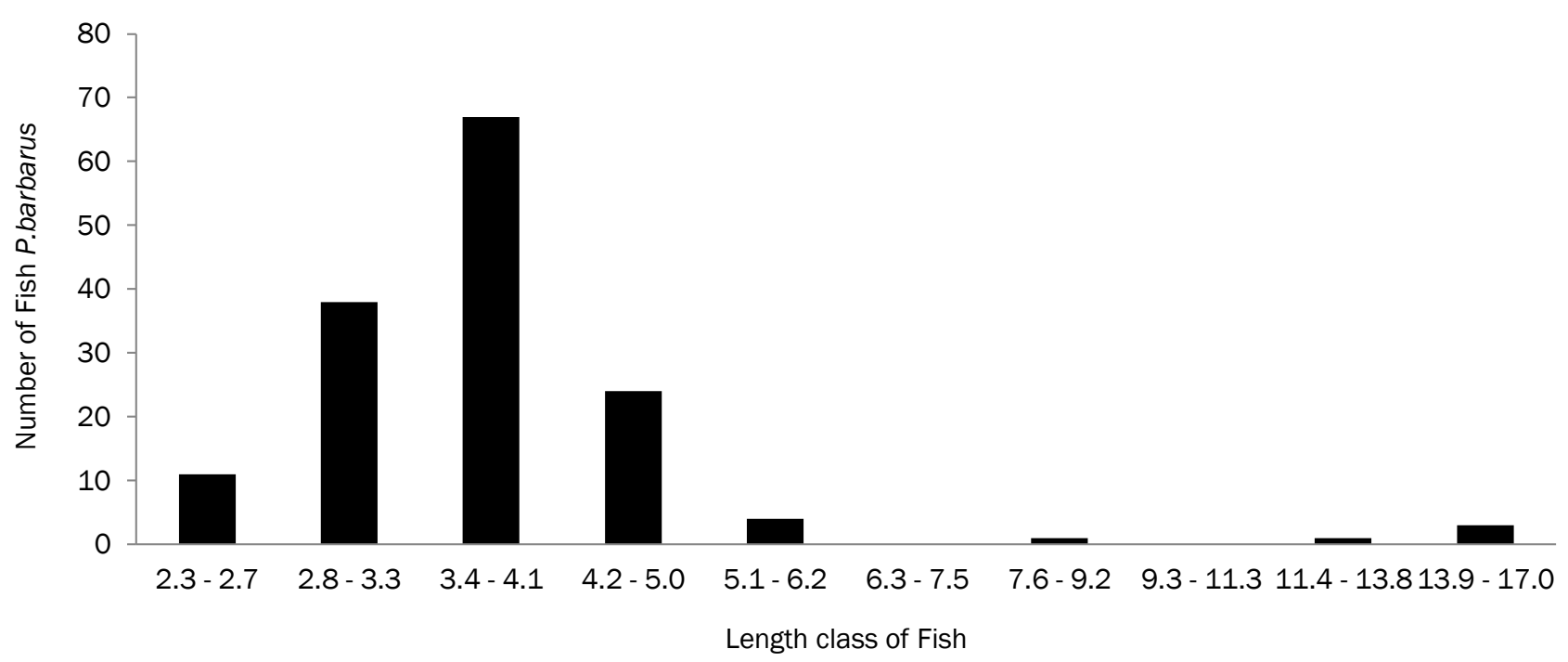

Figure 2. Distribution structure length of female $P$. barbarus in KKMB

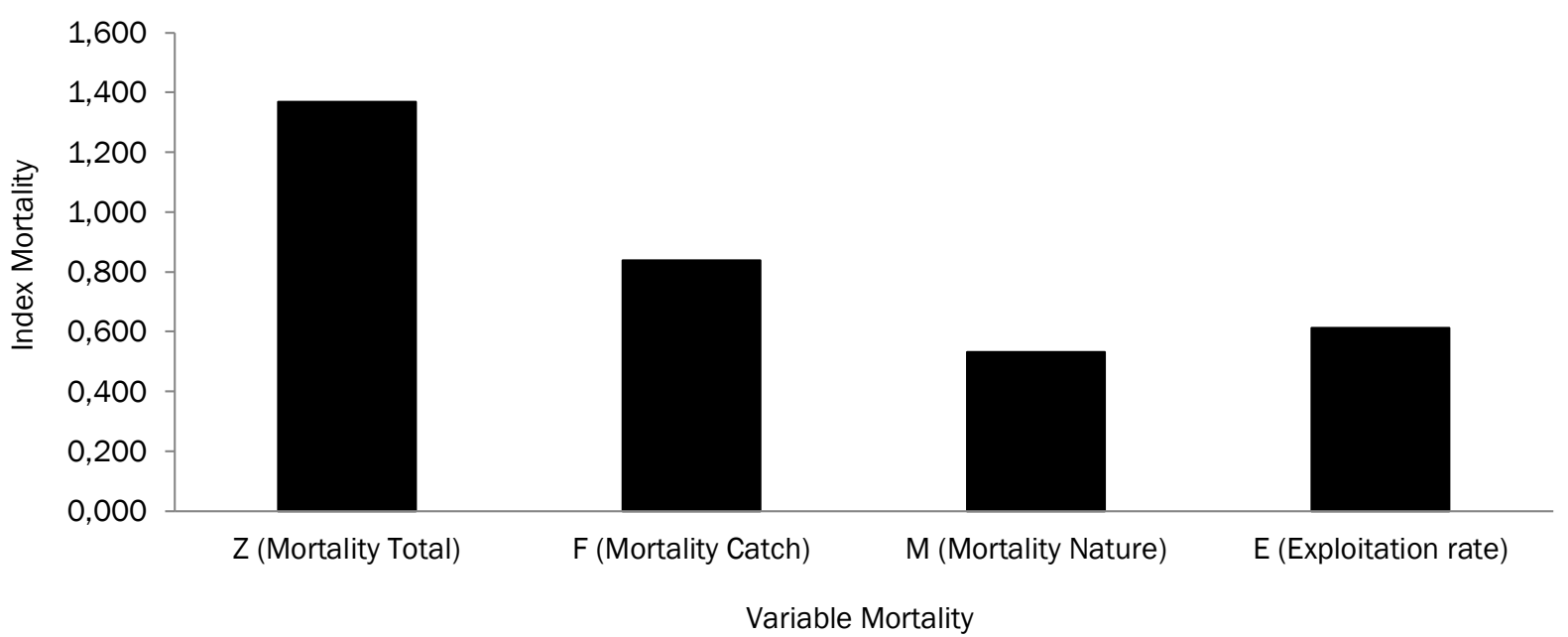

Figure 3. Mortality variable of male $P$. barbarus in KKMB

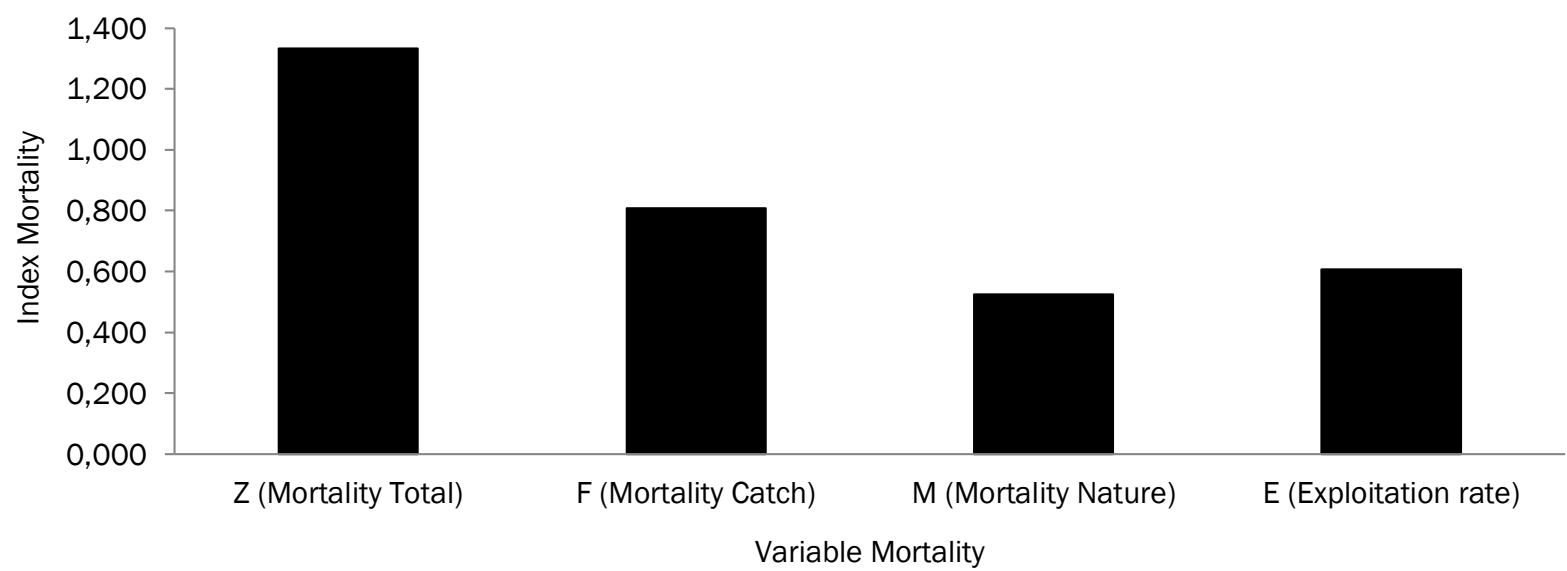

Figure 4. Mortality variable of female $P$. barbarus in KKMB 
result of regression linier between of them was $y=$ $0.0593 x+1.574$ with $69.79 \%$ correlation (Figure 5) and The orthogonal polynomial equation $6^{\text {th }}$ type was $y=-1 E-11 x^{6}+1 E-08 x^{5}-3 E-06 x^{4}+0.0004 x^{3}-0.032 x^{2}+$ $1.3449 x+2.1525$ with $99.99 \%$ correlation (Figure 6). Then, for female $P$. barbarus, the regression equation between total length and growth rate was $y$ $=-0.0719 x+1.265$ with $75.68 \%$ correlation (Figure $7)$. The orthogonal polynomial equation $6^{\text {th }}$ type was $y=-1 E-11 x^{6}+1 E-08 x^{5}-3 E-06 x^{4}+0.0004 x^{3}-$ $0.032 x^{2}+1.3449 x+2.1525$ with $99.99 \%$ correlation (Figure 8).

The regression graphic in figure 5 and 7 leads toward the axis. It indicates that the maximum length of male $P$. barbarus was $26.545 \mathrm{~cm}$, with growth rate was $0.0593 \mathrm{~cm}$.day ${ }^{-1}$ (Figure 5.). The maximum length of female $P$. barbarus was 17.594 $\mathrm{cm}$, with growth rate was $0.0719 \mathrm{~cm}$.day ${ }^{-1}$. However, the previous research by Firdaus and Salim (2018) about the maximum total length of male mudskipper was $27.374 \mathrm{~cm}$ with growth rate $0.0147 \mathrm{~cm}^{\text {day }}{ }^{-1}$. The maximum of female mudskipper was 20.683 $\mathrm{cm}$, with growth rate $0.00262 \mathrm{~cm}_{\text {day-1 }}{ }^{-}$. The comparison of data in 2015 and 2017 explain that growth of male and female mudskipper degrades. Furthermore, the degradation of maximum length growth of male and female mudskipper was 0.829 and $3.089 \mathrm{~cm}$, respectively. The amount of mudskipper population in 2015 and 2017 was 375 and 296, respectively. It indicates that there is a degradation population. This is in accordance with Salim et al., (2018) stated that there was decreasing of species amount and for body shape of $P$. barbarus was allometric negative due to competition in looking for food. However, the condition of Aquatic environment can affect the degradation of the species amount, one of them was in KKMB, Tarakan, there was a changing of river shape, like sedimentation and water pollution around the area cause the accumulation of plastic waste.

\section{Variable growth of allometric and index condition}

The result of allometric growth about correlation between length and the total weight of male mudskipper dominated with positive allometric (b value $>3$ ). The allometric growth of the female mudskipper is dominated by negative allometric (Figure 9) due to the feed competition in the habitat and energy to avoid the predator. Haris et al. (1999), explain that the growth of $P$. barbarus is affected by the environment system, like food availability, salinity, $\mathrm{pH}$, and temperature. The research of Firdaus and Salim (2018) explain that characteristic of male and female mudskipper is negative allometric. Latif (2016) clarifies that the research result of male and female mudskipper in $\mathrm{KKMB}$, Tarakan City is positive allometry. Based on (Effendie, 1979), Figure 9 shows that if $b$ value $=3$, the growth characteristic is isometric. If $b$ value $<3$, the growth characteristic is negative allometric. If $b$

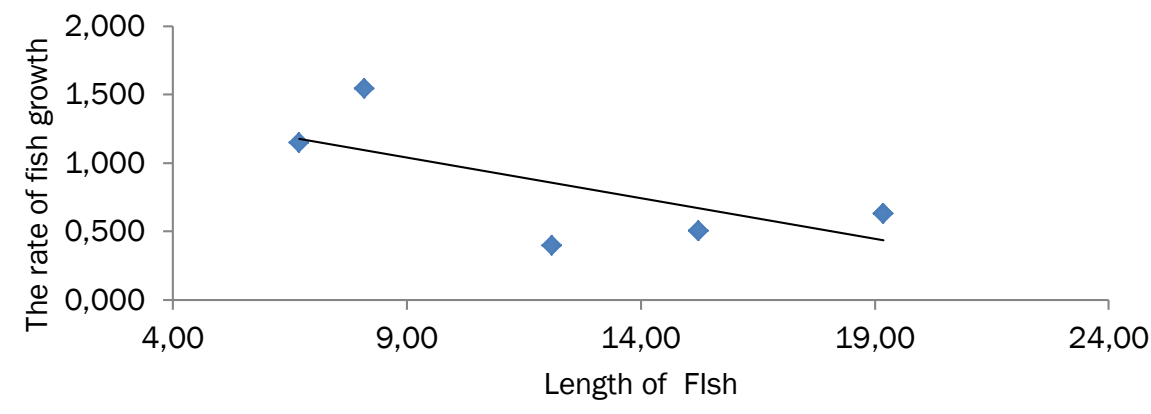

Figure 5. Von Bertalanffy relationship growth model and length of male $P$. barbarus

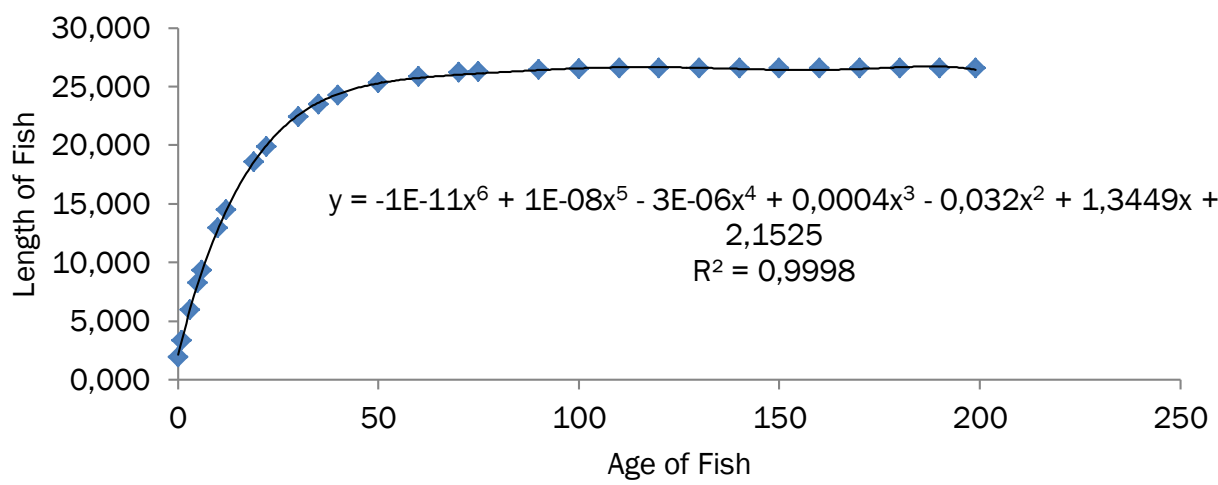

Figure 6. Von Bertalanffy polynomial orthogonal type 6 model of male P. barbarus 


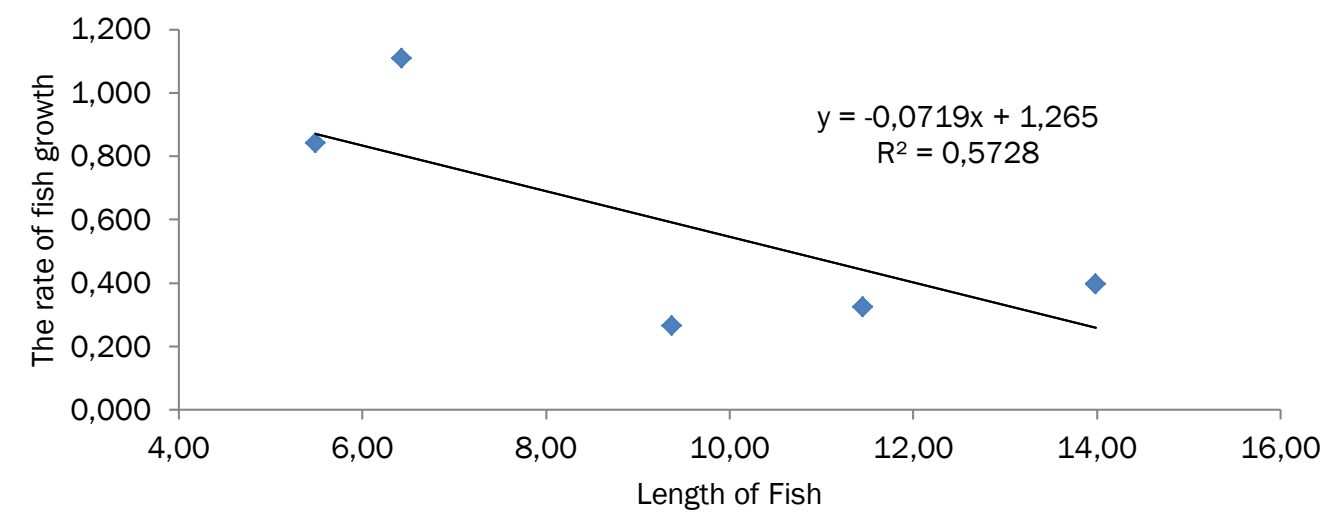

Figure 7. Von Bertalanffy relationship growth model and length of female $P$. barbarus

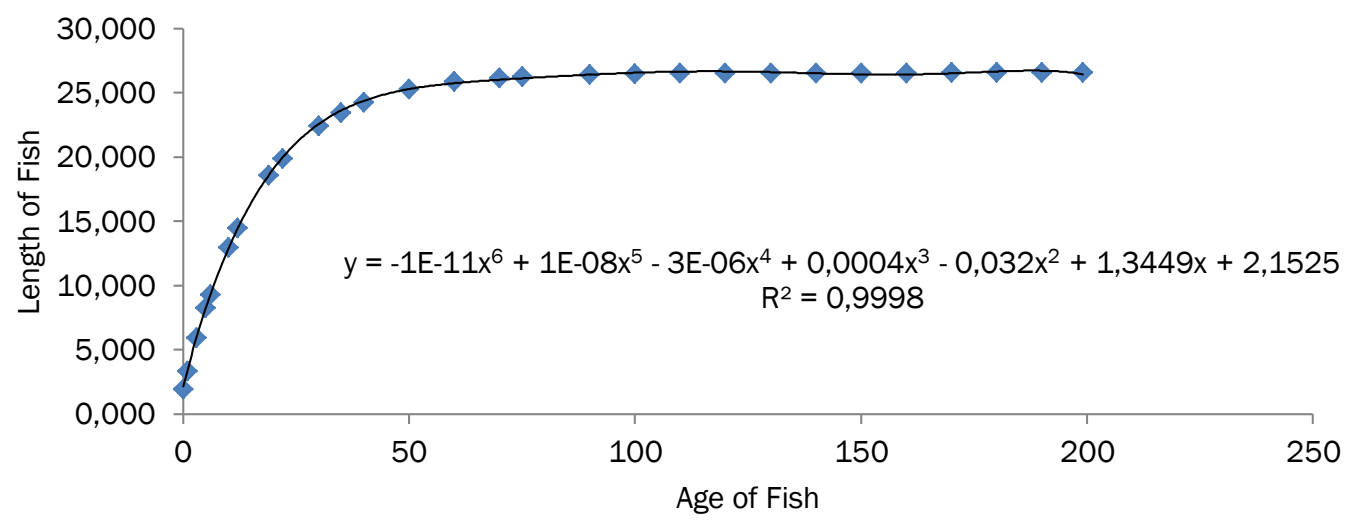

Figure 8. Von Bertalanffy polynomial orthogonal type 6 model of female $P$. barbarus

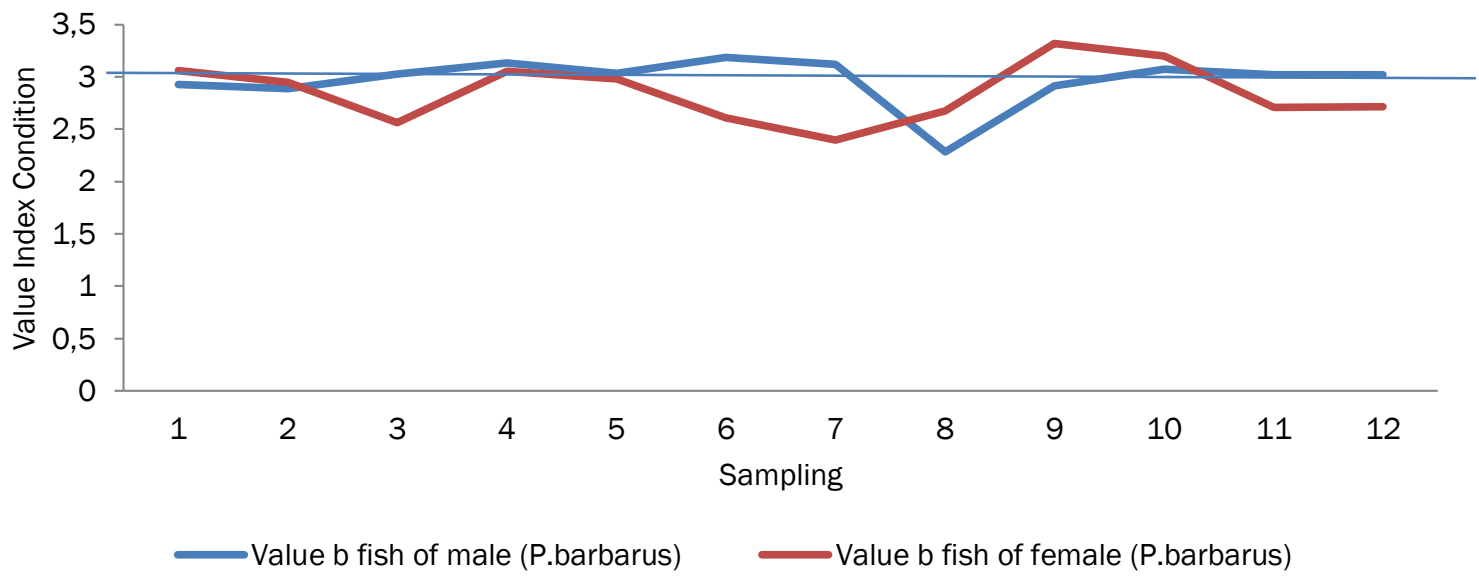

Figure 9. The Comparison of allometric growth in male and female

value $>3$, the growth characteristic is positive allometric. Figure 9 indicates that the average of the male $P$. barbarus growth is positive allometric; it corresponds to the condition index in figure 10. The average of male mudskipper body shape is fat. It is the difference with female $P$. barbarus, which has negative allometric, has fat and flat body shape.
(Muchlisin et al., 2010) explained that fish growth patterns were influenced by food availability and water conditions. The coefficient value (b) was influenced by fish behavior, where the active one showed value of $(b)<3$ than passive $(b>3)$. Probably, it related to the allocation of energy expended for its movement and growth (Muchlisin et al., 2010). 


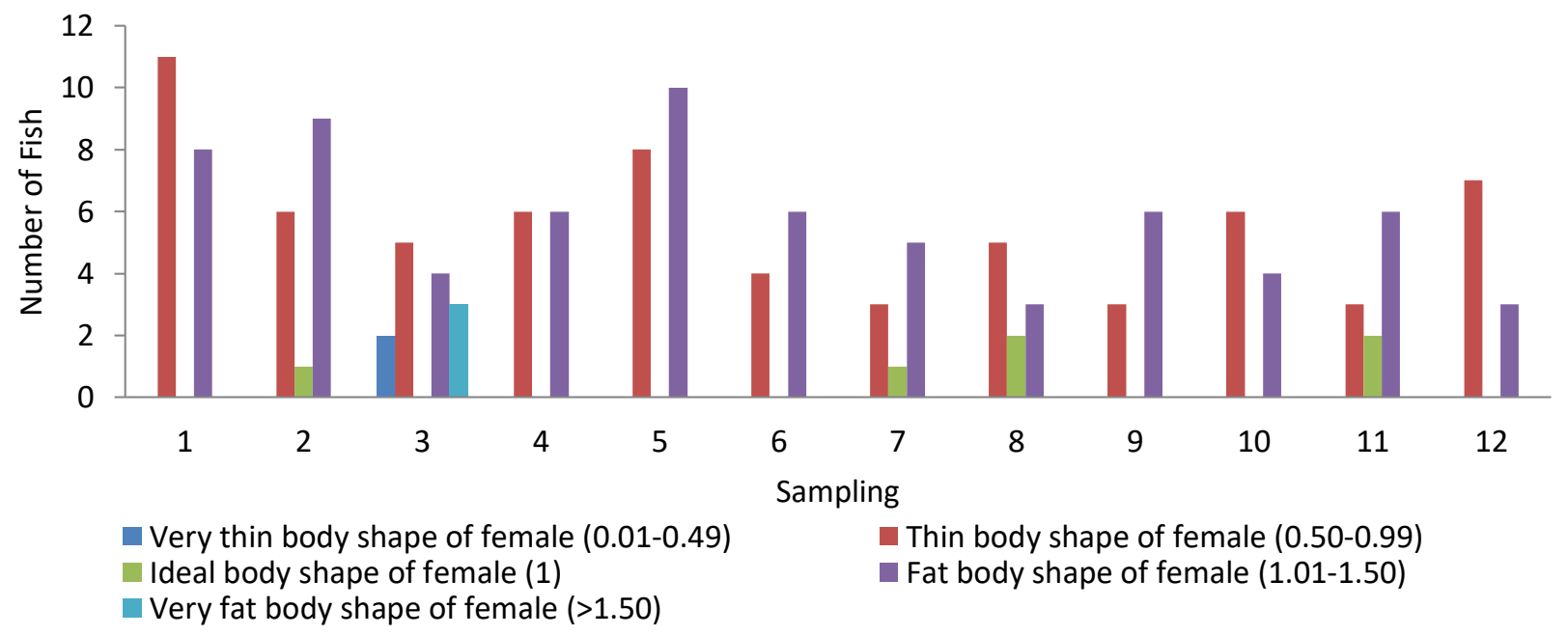

Figure 10. The body shape of female P. barbarus

\section{Mortality variable}

Mortality variable of the mudskipper consists two kinds. There are fishing and natural mortality. The requirement of $P$. barbarus as medicine and research object increased fishing mortality. In this research, the fishing mortality of male and female mudskipper was $83.77 \%$ and $80.77 \%$ every year, respectively. Natural mortality is caused by environment pollution, virus, bacteria, and predator. The natural mortality of male and female mudskipper is $53.14 \%$ and $52.54 \%$ every year, respectively. The exploitation rate of male and female mudskipper is $61.19 \%$ and $60.59 \%$ every year. The fishing category of $P$. barbarus is allowed, based on Nikijuluw (2002). The Maximum Sustainable Yield (MSY) is $80 \%$.

\section{Conclusion}

The conclusion of this research about the mudskipper in Mangrove and Bekantan Conservation area, Tarakan city are the male and female mudskipper growth sustained size degradation and amount of population. The length maximum of male $P$. barbarus was $26.545 \mathrm{~cm}$, with the growth rate was $0.0593 \mathrm{~cm} \cdot \mathrm{y}^{-1}$. The length maximum of female $P$. barbarus was $17.594 \mathrm{~cm}$, with the growth rate was $0.0719 \mathrm{~cm} \cdot \mathrm{y}^{-1}$. The growth characteristic of male mudskipper was positive allometric with fat body shape. The growth characteristic of female mudskipper was negative allometric with round body shape. The natural and fishing mortality of male mudskipper is higher than that of the female. The category of exploitation rate of male and female mudskipper is allowed.

\section{References}

Effendie, M.I. 1979. Metoda Biologi Perikanan. Yayasan Dewi Sri, Bogor.

Firdaus, M., Lelono, T.D., Saleh, R., Bintoro, G., \& Salim, G. 2018. The expression of the body shape in fish species harpadon nehereus (Hamilton, 1822) in the waters of juata laut, tarakan city, north kalimantan. AACL Bioflux 11(3): 613-624

Firdaus, M. \& Salim, G. 2011. Mengkaji Populasi Ikan Puput (Ilisha elongata) yang Berasal dari Perairan Kota Tarakan. J. Harpodon Borneo, 4: 46-53. doi : 10.35334/harpodon.v4i1.62

Firdaus, M. \& Salim, G. 2018. Study population of mudskipper (Periophthalmus barbarus) in Bekantan and Mangrove conservation area, Tarakan city, North Kalimantan. Borneo Saintek of University of Borneo Tarakan J. 1: 68-78.

Jamiludin \& Salim, G. 2016. Analisis Rasio Kelamin dan Kepadatan Ikan Tempakul (Periopthalmus barbarus) di Kawasan Konservasi Mangrove dan Bekantan Kota Tarakan. J. Akuatika Indo. UNPAD 2: 139-147.

Lagler, K.F., 1949. Studies in freshwater fishery biology. The Progressive Fish-Culturist, 11(3): 194-194.

Latif, A.A. 2016. Studi Pupulasi Dan Morfometri Ikan Tempakul (Periopthalmus Sp) Di Kawasan Konservasi Mangrove Dan Bekantan (KKMB) Kota Tarakan: $41 \mathrm{pp}$. 
Muchlisin, Z.A., Musman, M. \& Siti Azizah, M.N. 2010. Length-weight relationships and condition factors of two threatened fishes, Rasbora tawarensis and Poropuntius tawarensis, endemic to Lake Laut Tawar, Aceh Province, Indonesia. J. App. Ichthyolog., 26: 949-953. doi : 10.1111/j.1439-0426.20 10.01524.x

Nash, R.D.M. 1984. Aspects of the biology of the black goby, Cobius niger L., in Oslofjorden, Norway. Sarsia, 69: 55-61. doi : 10.1080/ 00364827.1984 .10420589

Nikijuluw, V.P.H. 2002. Fisheries Resource Management Regime. Regional Empowerment and Development Center.

Pauly, D. 1984. Fish population dynamics in tropical waters: a manual for use with programmable calculators. International Center for Living Aquatic Resources Management, Manila.

Salim, G. 2013. Nilai indeks kondisi dari ikan siganus javus berdasarkan hasil tangkapan nelayan di Perairan Juata Kota Tarakan. Jurnal
Harpodon Borneo 8: 37-42. doi :10.35334 /harpodon.v6i1.99

Salim, G. 2015. Analisis Pertumbuhan Allometri dan Indeks Kondisi Caesio cunning Didapatkan dari Hasil Tangkapan Nelayan Kota Tarakan. Jurnal Harpodon Borneo 8: 35-42.

Salim, G., Weliyadi, E. \& Susiyanti 2018. Model Pertumbuhan Populasi Ikan Gelodok ( $P$. barbarus) di Kawasan Konservasi Mangrove Bekantan Kota Tarakan 1: 66-74.

Silva, M.N., \& Gordo, L.S. 1997. Age, growth and reproduction of the black goby, Gobius niger, from Obidos Lagoon, Portugal. Cahiers de Biologie Marine 38:175-180.

Sparre, P., \& Venema, S.C. 1998. Introduction to tropical fish stock assessment. Part 1: Manual. FAO Documento Técnico de Pesca. №. 306.1 Rev. 2.

Weatherley, A.H. 1972. Growth and Ecology of Fish population. Academic Press, New York. 